\title{
Indices of Water Quality and Pesticide Monitoring Survey in Lake of Western Côte d'Ivoire and Its Human Risk Assessment
}

\author{
Kouamé Kouakou Benoit ${ }^{1}$, Konan Kouakou Séraphin1, Konan Koffi Félix², \\ Boussou Koffi Charles ${ }^{2}$, Kouamé Kouamé Martin², Dibi Brou ${ }^{1}$ \\ ${ }^{1}$ Laboratory of Geosciences and Environment, University Jean Lorougnon Guédé, Daloa, Côte d'Ivoire \\ ${ }^{2}$ Laboratory of Ecology, Biodiversity and Evolution, University Jean Lorougnon Guédé, Daloa, Côte d'Ivoire \\ Email: benoitk322@gmail.com,konandks@yahoo.fr
}

How to cite this paper: Benoit, K.K., Séraphin, K.K., Félix, K.K., Charles, B.K., Martin, K.K. and Brou, D. (2020) Indices of Water Quality and Pesticide Monitoring Survey in Lake of Western Côte d'Ivoire and Its Human Risk Assessment. Natural Resources, 11, 46-69.

https://doi.org/10.4236/nr.2020.112004

Received: January 26, 2020

Accepted: February 25, 2020

Published: February 28, 2020

Copyright $\odot 2020$ by author(s) and Scientific Research Publishing Inc.

This work is licensed under the Creative Commons Attribution International License (CC BY 4.0).

http://creativecommons.org/licenses/by/4.0/

(c) (i) Open Access

\begin{abstract}
The aims of the work were to study the current quality of the water in Lake DOHOU used for drinking water supply through several physical, chemical analyses and using water quality indices (WQI). In addition, the question was whether the populations are at risk after drinking water of lake following a reduction of $50 \%$ and $75 \%$ in the median and maximum values of pesticides. Thus, the results of the pesticide monitoring program were incorporated into probabilistic human health risk assessment exercises. Water samples were collected over a period of one year. Pesticides were subjected to solid phase extraction and then analyzed using gas chromatography coupled to tandem mass spectroscopy. The other parameters were measured according to conventional methods. The results showed that the most frequently detected pesticides were aldicarb (79\%), simazine (79\%) and monolinuron (44\%). They also showed the mean values of concentrations exceeding $1.5 \mu \mathrm{g} / \mathrm{L}$. Metoxuron detected at a frequency of $29 \%$ showed the maximum average concentration $(13.46 \mu \mathrm{g} / \mathrm{L})$. Nearly $98 \%$ of the sampling points had at least one substance with an average concentration above the quality standard $(0.1 \mu \mathrm{g} / \mathrm{L})$ and $80 \%$ did not meet the total concentration standards. Cumulative risk quotient estimates after $50 \%$ or $75 \%$ abatement for frequently identified pesticides were greater than unity when extreme values for adults and children were considered. To determine the suitability of water for aquatic life, drinking water consumption and drinking water production, the water quality index (WQI), the heavy metal pollution (HPI) and the heavy metal evaluation (HEI) were calculated. The poor quality of the water was mainly related to pesticides, organic matter and microbiological parameters. Most of the nutrients and metals studied were often below the standards of drinking water
\end{abstract}


and aquatic life. The Water Quality Index (WQI) has shown that water quality is degrading for these three modes of use and ranges from poor to marginal. The coupling of monitoring data with probabilistic estimates of human risks could be used by the Ivorian authorities to propose effective pollution management plans.

\section{Keywords}

Pesticides, Health Risk Assessment, Water Quality Index, Heavy Metal Index

\section{Introduction}

Agriculture occupies a prominent place in developing countries because of its food, economic, social and environmental functions [1]. However, it faces many difficulties related to land insecurity, non-mechanization and rainfall problems [2]. To these basic problems is added the parasitic pressure exerted on the crops. All these factors combine to reduce production and consequently farmers' incomes. Thus, there is a question of survival for the latter who must find solutions to these constraints. If the resolution of land, water and mechanical problems is generally beyond the reach of the common farmer, it is different for the management of parasitism and weed issues [3]. The solution is based on the massive application of phytosanitary products, sometimes prohibited, and which ultimately poses environmental and health problems [4]. Also, in recent years, there has been a population growth in Côte d'Ivoire, accompanied by intensive urbanization, the development of industrial activities and the exploitation of arable land [5]. This has resulted in a large increase in wild dumping and a wide diversification of pollutants that can reach watercourses. The precariousness of Dohou Lake raises serious concerns because of the above-mentioned causes in addition to the absence or poor quality of drainage and sanitation structures. The main consequences of this gloomy picture are the inadequacies in the supply of drinking water and indirectly diarrheal diseases induced by the pathogens responsible for about 3.4 million deaths worldwide through the direct or indirect consumption of water contaminated [6]. The populations are thus faced with the often-fatal consequences of the drifts of their activities. Moreover, in Côte d'Ivoire, there are very few drinking water stations supplied by surface water that offer a moderately sophisticated treatment; that is to say, a filtration treatment accompanied by ozone treatment or activated charcoal. Since the majority of drinking water treatment plants supplied by surface water in Côte d'Ivoire do not provide a treatment that can remove all pesticides and trace elements present in the raw water, it is essential to ensure that surface water is not contaminated by these pollutants. Pollutants are generally in large quantities in urban discharges [7]. Data from the literature indicate that their release into aquatic environments adversely affects the physicochemical quality of biotopes and affects organisms at different levels of biological organization [8]. Pollution of wa- 
ter by pesticides is particularly problematic because of the ecological and human challenge that this resource represents [9]. The quality of surface water is therefore an issue for the population. Most of the surface water resources, particularly in peri-urban areas, are confronted with these pollutions, which causes them to experience episodes of eutrophication, due to nutrient inputs from domestic waste and agriculture. With regard to agricultural pollution, pollutants can lead to contamination of the food chain, difficulties in supplying populations with drinking water and certain threats to biodiversity [10]. These consequences are due to the persistence of certain agrochemicals or their degradation products which, through bioaccumulation and biomagnification, accumulate in the tissues of plants and animals [11]. In addition, the contamination of surface waters by heavy metals is a serious environmental problem because of their potential toxicity to humans and the environment [12]. They are not biodegradable and can bioaccumulate throughout the food chain. The interpretation of water quality datasets for pollution assessment is quite difficult because of the simple elemental concentrations [13]. On the other hand, quality indices have a great deal of leeway in analyzing data sets for better interpretation of pollution [14]. The present study aimed to evaluate the current water quality of Dohou Lake through several physical and chemical analyzes, using water quality indices (WQI), heavy metal pollution (HPI), heavy metals evaluation (HEI) and monitoring of 32 pesticides and metabolites in this lake used for drinking water supply. In addition, the results of the pesticide monitoring program have been incorporated into probabilistic risk assessment exercises for human health.

\section{Materials and Methods}

\subsection{Study Area and Physicochemical Analysis}

A mesh of the lacustrine water body allowed to select the sampling sites shown

in Figure 1. Seven water quality monitoring points were set up on Dohou Lake

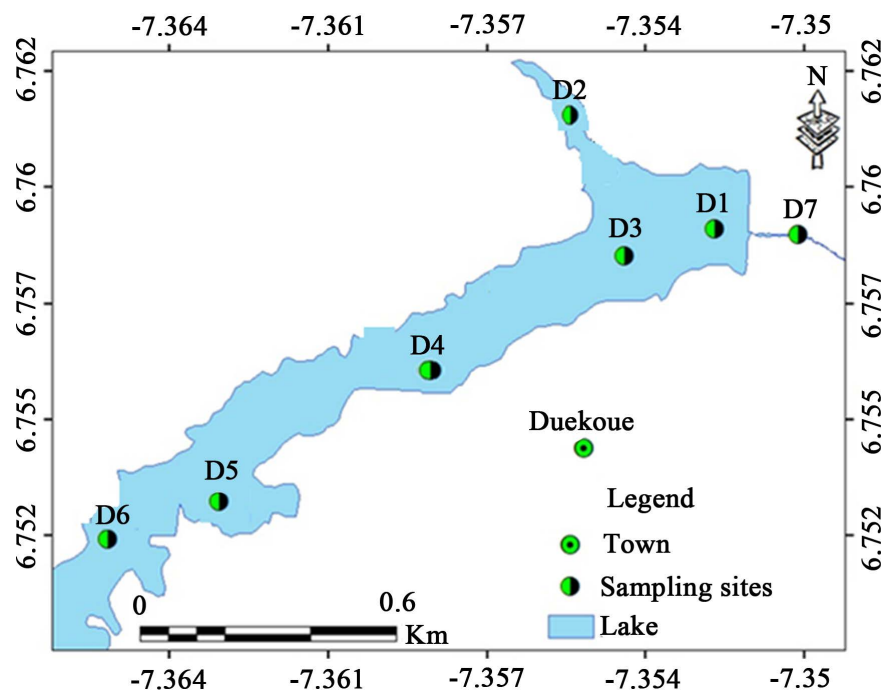

Figure 1. Map of sampling sites of Dohou Lake [15]. 
used for the production of drinking water with an area of one square kilometer. The study area is Guemon. It is a region with high agricultural production. Water samples were collected just below the surface of the water for analysis of selected parameters. The analysis was performed on several physical, chemical and microbiological parameters. Some parameters such as $\mathrm{pH}$, dissolved oxygen and TDS were measured in situ using a multi-parameter HANNA brand, HI 9828 and other chemical and microbiological variables were estimated according to the procedures described by [15].

\subsection{Heavy Metals Analysis}

Seasonal samples of surface water were collected from November 2017 to October 2018. Samples were collected at the same location over the four seasons. The reagent used for sampling and filtration is $\mathrm{HNO}_{3}$ pure quality $48 \%$. The objective is to stabilize the solutions at $\mathrm{pH}=2$ to minimize precipitation and adsorption on the bottle walls, as required by the standard procedure. The sample bottle is rinsed with a little sample before filling. All samples once taken are stored in a cooler, and within a maximum of 24 hours placed in a refrigerator at $4^{\circ} \mathrm{C}$. The filtration apparatus is cleaned regularly with $1 \mathrm{~N} \mathrm{HCl}$ and rinsed with water to avoid memory effects on the collected water. The water samples were placed in clean polyethylene bottles. Heavy metal concentrations were determined using atomic absorption spectrometry (Perkin-Elmer, 3300/96, MHS-10) with a specific lamp for each particular metal. The heavy metal concentrations $\mathrm{Pb}, \mathrm{Cd}, \mathrm{Fe}$, $\mathrm{Zn}, \mathrm{Mn}$ and $\mathrm{Cu}$ were analyzed by flame atomic absorption spectrometry. Arsenic and mercury were determined by atomic absorption spectrometry with hydride/cold vapor generation. Lead was determined by atomic absorption spectrometry in a graphite furnace. The average values of three repetitions were taken for each determination. The quality of the analytical data has been ensured through the implementation of quality assurance and quality control methods in the laboratory, including the use of standard operating procedures, calibration with standards, analysis of blanks reagents, recovery of known additions and replica analysis. All analyzes were performed in triplicate and the results were expressed as an average. In order to minimize the variability among the sample results, we used the same analytical laboratory and this laboratory applied the same method of analysis for each chemical element searched during the study period.

\subsection{Pesticide Analysis}

Before extraction, the samples were filtered under vacuum through a filter paper to remove the particles. Each sample was returned to its original sampling container. The principle of SPE is to allow a volume of $10 \mathrm{~mL}$ of sample to pass through a plastic cartridge containing octadecyl (C18). Before use, the cartridges were preconditioned with $4 \mathrm{ml}$ of methanol then $4 \mathrm{ml}$ of distilled water. The water samples were loaded onto the cartridges at a rate of $5 \mathrm{ml} \cdot \mathrm{min}^{-1}$. After sample percolating, the cartridges were aerated by pumping air and the retained solutes 
were eluted with $5 \mathrm{ml}$ of an ethyl acetate: methanol mixture $(10 \mathrm{v} / \mathrm{v})$ followed by $4 \mathrm{ml}$ of hexane, leaving to soak for 30 minutes. The combined eluate was evaporated to dryness and the residue was dissolved in $100 \mu \mathrm{L}$ of ethyl acetate. Once the extraction process is complete, the next step is the analysis consisting of the separation, identification and determination of the isolated substances. In the case of the pesticides in this study, the technique used is that of gas chromatography (GC) coupled with mass spectrometry. For the analysis of the molecules in this study, it was coupled with several types of detectors such as the NPD detector and the mass spectrometer. The apparatus used is a Varian ${ }^{\circledR}$ 431-GC chromatograph (Agilent Technologies, Les Ulis, France) equipped with an automatic sample changer (Varian ${ }^{\otimes} \mathrm{CP}-8410$ ) coupled to a Varian ${ }^{\oplus} 210-\mathrm{MS}$ mass spectrometer operating with a charge trapping analyzer (ion trap). Mass spectrometer was used in full scan mode. The whole is controlled by a computer equipped with software allowing the acquisition and the exploitation of the data. The temperature program applied to the column is as follows: the flow temperature is $70^{\circ} \mathrm{C}$ then rises to $175^{\circ} \mathrm{C}$ with a step of $10^{\circ} \mathrm{C} / \mathrm{min}$, then to $225^{\circ} \mathrm{C}$ with a step of $5^{\circ} \mathrm{C} / \mathrm{min}$ and finally at $310^{\circ} \mathrm{C}$ at a rate of $10^{\circ} \mathrm{C} / \mathrm{min}$. The final temperature of $310^{\circ} \mathrm{C}$ is maintained for $6 \mathrm{~min} 50 \mathrm{sec}$. The injection was done in spitless mode for 30 seconds with an injector temperature of $280^{\circ} \mathrm{C}$. A sample volume of $2 \mu \mathrm{L}$ is injected using the autosampler to obtain a good reproducibility of the injection. The mass spectrometer is used in electronic impact (EI) mode where ionization is caused by collisions with electrons at $70 \mathrm{eV}$; the intensity of the filament was $80 \mu \mathrm{A}$. The pesticides were identified by comparing the retention times obtained by analyzing a standard mixed working solution at $500 \mathrm{ppb}$ and by interrogating the software's mass spectra library. The pesticide contents contained in the samples are calculated by comparing the areas of the peaks of the products in the sample with the areas obtained with standard solutions of known concentrations. The principle of calculation of the results by the software is given by the Equation (1)

$$
C_{p}=\frac{S_{c} \times C_{e} \times V_{2} \times V_{f} \times F}{S_{e} \times M_{e} \times V_{1}}
$$

$C_{p}$ : concentration of active ingredient $(\mathrm{mg} / \mathrm{L}) ; S_{c}$ : peak area of the sample; $S_{e}$ : standard peak area; $C_{e}$ : standard concentration $(\mathrm{mg} / \mathrm{L}) ; V_{1}$ : volume to be purified (1); $V_{2}$ : volume after purification (1); $V_{\dot{f}}$ final volume (l); $M_{e}$ : sample volume (l); $F$ : dilution factor.

\subsection{Heavy Metal Pollution Index (HPI) and Heavy Metals Evaluation Index (HEI)}

The degree of metallic pollution in the Dohou Lake water samples was evaluated using two methods: the metal pollution index (HPI) and the heavy metals evaluation index (HEI) as reported by [14] and [16]. HPI indicates the quality of water and its suitability for use as drinking water for metals [17]. The Heavy Metal Pollution Index (HPI) method was developed by assigning a rating or weighting $\left(W_{i}\right)$ to each selected parameter $(\mathrm{Hg}, \mathrm{Cd}, \mathrm{As}, \mathrm{Pb}, \mathrm{Cu}, \mathrm{Fe}, \mathrm{Mn}, \mathrm{Zn})$. The Heavy 
Metals Evaluation Index (HEI) provides an overview of the overall water quality for heavy metals and metalloids ( $\mathrm{Hg}, \mathrm{Cd}, \mathrm{As}, \mathrm{Pb}, \mathrm{Cu}, \mathrm{Fe}, \mathrm{Mn}, \mathrm{Zn}$ ) [18]. It was calculated by [17] as follows:

$$
\mathrm{HPI}=\sum_{i=1}^{n} Q_{i} W_{i} / \sum_{i=1}^{n} W_{i}
$$

With

$$
Q_{i}=\sum_{i=1}^{n} \frac{M_{i}-I_{i}}{S_{i}-I_{i}} \times 100 \text { and } \mathrm{HEI}=\sum_{i=1}^{n} H_{C} / H_{M A C}
$$

where $Q_{i}$ : sub-index of the nth parameter, $W_{i}$ : unit weighting of the parameter $i$, $n$ : number of parameters considered. $M_{i}$ : measured heavy metal content of the parameter $i, I_{i}$ ideal values of the parameter $i$ and $S_{i}$ standard value of the parameter $i$, the sign (-) indicates the numerical differences between the two values, ignoring the algebraic sign. $H_{\dot{c}}$ measured heavy metal content of parameter $i$, $H_{\text {mac }}$ maximum permissible concentration of parameter $i$.

\subsection{Water Quality Index}

In general, the index is used to assess water quality in relation to its desired status (as defined by the water quality objectives) and to give an idea of the extent to which water quality is affected by human activity. An index is a useful tool to describe the state of the water column, sediments and aquatic life and to assess the suitability of water for use by humans, aquatic life, wildlife.

The WQI is identified by the Canadian Water Quality Index approved by the Canadian Council of Ministers of the Environment [19]. The index has three components: Scope-number of variables that do not meet water quality objectives; frequency-the number of times these goals are not achieved; and amplitude-the sum of objectives has not reached. The index produces a number between 0 (worst water quality) and 100 (best water quality). The classification of WQI scores was illustrated by 5 descriptive categories to simplify the presentation of water quality: poor (0 to 44 ), marginal (45 to 64 ), fair (65 to 79 ), good ( 80 to 94 ) and excellent (95 to 100). The WQI was calculated using the Equation (4):

$$
\mathrm{QWI}=100-\frac{\sqrt{F_{1}^{2}+F_{2}^{2}+F_{3}^{2}}}{1.732}
$$

where $F_{1}$ (Scope) represents the percentage of variables that did not meet their objectives at least once during the reporting period ("failed variables"), relative to the total number of variables measured,

$F_{1}=\frac{\text { Number of failed variables }}{\text { Total number of variables }} \times 100 ; F_{2}$ (Frequency) represents the percentage of individual tests that do not meet the objectives ("failed tests"):

$F_{2}=\frac{\text { Number of failed tests }}{\text { Total number of tests }} \times 100, F_{3}$ (Amplitude): The extent (excursion) to which the failed test exceeded the permissible value.

The sum of non-compliance of the individual tests is calculated by summing the differences of the individual tests in relation to their objectives and dividing 
by the total number of tests (objectives exceeded by not achieved). This variable, called the normalized sum of excursions or nse, is calculated as follows:

$$
\text { nse }=\frac{\sum_{i=1}^{n} \text { excursion }_{i}}{\text { Total number of tests }}
$$

and

$$
\text { excursion }_{i}=\left(\frac{\text { Failed tests }_{i}}{\text { Guidline value }_{j}}\right)-1
$$

$F_{3}$ is then calculated by an asymptotic function that fits the normalized sum of the deviations to objectives (nse) to give a range between 0 and 100 .

$$
F_{3}=\frac{\text { nse }}{\text { nse } \times 0.01+0.01}
$$

Three sets of guidelines were used to determine if Dohou Lake is suitable for drinking water production according to the French standard FQWS [20], for direct use as source of drinking water WHO [21] and for the protection of aquatic life according to CCME criteria. Water quality was determined by 19 parameters $\left(\mathrm{NO}_{2}^{-}, \mathrm{NO}_{3}^{-}, \mathrm{NH}_{4}^{+}, \mathrm{pH}, \mathrm{OD}\right.$, total phosphorus, total nitrogen khjedjal, $\mathrm{Hg}$, $\mathrm{Pb}, \mathrm{Cd}, \mathrm{As}, \mathrm{Cu}, \mathrm{Fe}, \mathrm{Zn}, \mathrm{E}$. coli, enterococci, Aldicarb and Monolinuron), 24 (TDs, $\mathrm{BOD}_{5}, \mathrm{NO}_{2}^{-}, \mathrm{NO}_{3}^{-}, \mathrm{NH}_{4}^{+}, \mathrm{PO}_{4}^{3-}, \mathrm{SO}_{4}^{2-}, \mathrm{pH}, \mathrm{DO}$, total phosphorus, total nitrogen khjedjal, $\mathrm{Hg}, \mathrm{Pb}, \mathrm{Cd}, \mathrm{As}, \mathrm{Cu}, \mathrm{Fe}, \mathrm{Zn}, \mathrm{E}$. Coli, Enterococci, Aldicarb and Monolinuron) and 21 (TDS, $\mathrm{NO}_{2}^{-}, \mathrm{NO}_{3}^{-}, \mathrm{NH}_{4}^{+}, \mathrm{PO}_{4}^{3-}, \mathrm{SO}_{4}^{2-}, \mathrm{pH}, \mathrm{OD}$, $\mathrm{Hg}, \mathrm{Pb}, \mathrm{Cd}, \mathrm{As}, \mathrm{Cu}, \mathrm{Fe}, \mathrm{Zn}, \mathrm{E}$ coli, enterococci, Aldicarb and Monolinuron) for [19] [20] and [21], respectively.

\subsection{Risk Assessment for Human Health}

The non-carcinogenic risk of the detected pesticides was calculated using a model described by [22] and [23] for adults and children. Oral reference doses were obtained from [23] [24] [25]. Daily drinking water consumption per person depends on physical activity (duration and intensity of exercise), weather conditions and transpiration rate. The different types of surface water treatments have varying levels of effectiveness for pesticide removal from supply water. A study carried out in Switzerland and France established that the average pesticide abatement in their drinking water was $50 \%$ for conventional treatment (sand filtration) and $75 \%$ for filtration treatment accompanied by ozone [26]. Based on these results, we calculated the different allowances on the median values and the maximum values (Table 4) this study two scenarios were used, the first considering the raw water consumption of the lakes and the second, more realistic, lake water consumption after treatment. The hazard quotient (HQ) was used to calculate the non-carcinogenic hazard for a person consuming water from this resource (Equation (5)) [23] [27]. Pesticides with a high detection frequency and some with an oral reference dose were considered in this work. Other routes of exposure (e.g. skin contact with surface water during shower) have not been considered. 


$$
\mathrm{HQ}=\frac{\mathrm{CDI}}{\mathrm{RfDo}}
$$

where the daily intake (CDI) represents the estimated amount of pesticide ingested per kilogram of body weight; The reference dose (RfDo) is the reference dose of the contaminant $(\mathrm{mg} / \mathrm{kg} /$ day) orally. The CDI was calculated by the Equation (6) [22],

$$
\mathrm{CDIi}=\frac{\mathrm{C} \times \mathrm{IRi} \times \mathrm{EFi} \times \mathrm{EDi}}{\mathrm{BWi} \times \mathrm{AT}}
$$

where $\mathrm{C}$ represents the measured concentration $(\mathrm{mg} / \mathrm{L})$ of each pesticide in the water (median and maximum concentration detected), IRi is the water ingestion rate ( 1.5 and $2 \mathrm{~L}$ /day for each age considered, 6 years for children and 70 years for adults) [28], EFi is the frequency of exposure (350 days/year for both ages), EDi is the exposure duration (6 years for children and 70 years old for adults). BWi is the body weight of the exposed person $(28 \mathrm{~kg}$ for children and $70 \mathrm{~kg}$ for adults, AT is the average lifespan (2190 and 25,550 days for children and adults, respectively). When HQ of a pesticide was greater than 1, potential adverse effects were probably due to the compound in question, and if HQ was less than 1, adverse effects were not likely. To estimate the cumulative potential (HQs) of several pesticides, the sum of the hazard quotients for each pesticide was calculated by the Equation (7)

$$
\text { HQs }=\sum \text { HQi }
$$

\section{Results}

\subsection{Pesticides}

A total of 28 water samples were analyzed for 32 pesticides and their metabolites over a one-year sampling period. Twenty-two pesticides and their metabolite products were detected in the lake. Sixteen herbicides (atrazine, metolachlor, prometryn, diuron, isoproturon, metamitron, metazachlor, simazine, terbuthylazine, terbutryn, monolinuron, fenuron, metoxuron, monuron, metobromuron and linuron), six insecticides-acaricides (parathion-methyl, vinchlozoline, parathion-ethyl, Chlorfenvinphos, Chlorpropham and Aldicarb) and two metabolites (atrazine-desethyl, atrazine-deisopropyl) were quantified. During the study period of the 32 different substances investigated, 17 were more or less frequently detected, including 16 at concentrations above $0.1 \mu \mathrm{g} / \mathrm{L}$ and 15 at concentrations above $0.5 \mu \mathrm{g} / \mathrm{L}$. On average, 6 substances were detected simultaneously in the same samples. In $85 \%$ of the samples, the cumulative concentration exceeded 0.5 $\mu \mathrm{g} / \mathrm{L}$. The most frequently quantified substances (frequency $>40 \%$ ) during the study period were in ascending order, Monolinuron, Simazine and Aldicarb (Figure 2(a)). Generally, herbicides were the most frequently detected pesticides and showed higher concentration values. For the insecticides that were detected in $45 \%$ of the samples, the main families represented were carbamates (aldicarb) and organophosphorus compounds (parathion-methyl, parathion-ethyl, chlorfenvinphos). The behaviors of the active ingredients may depend to 


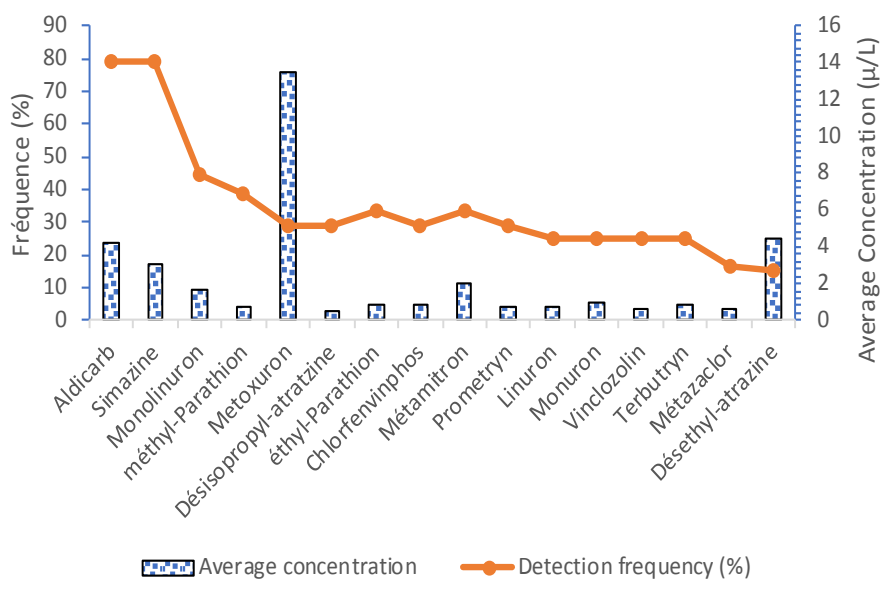

(a)

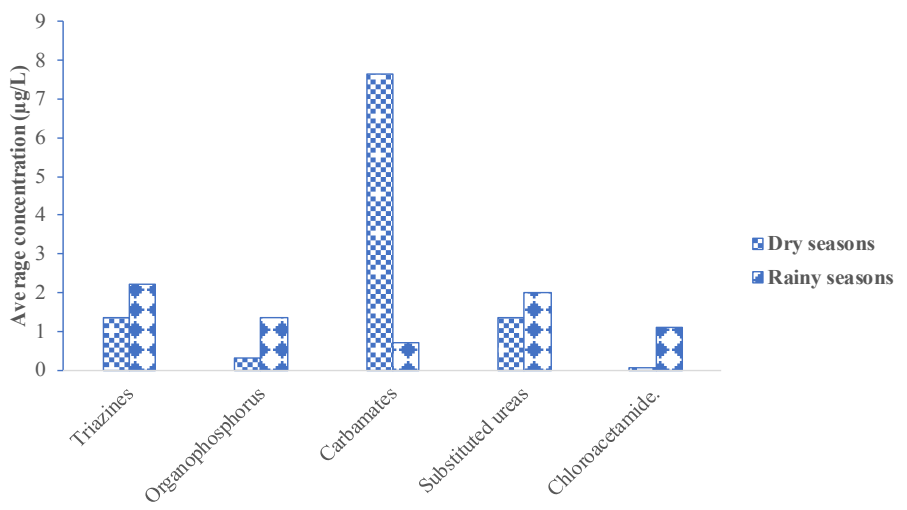

(b)

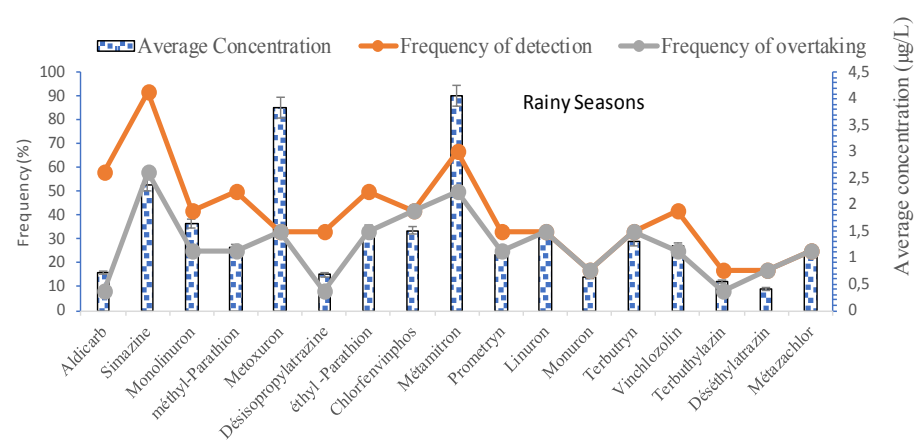

(c)

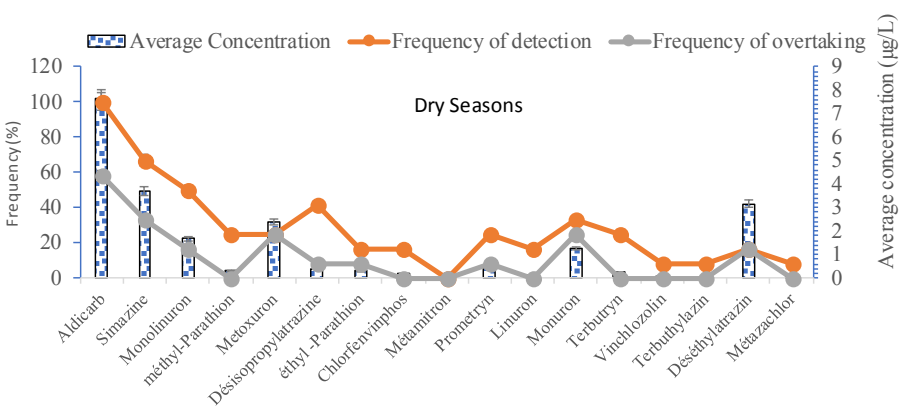

(d)

Figure 2. Mean concentrations, detection frequencies and overtaking of pesticides according to the seasons. 
a certain extent on the seasons. Indeed, climatic parameters such as temperature, rain, wind and sunshine play a key role in the fate of pesticides, hence the relevance of the study of seasonal variations in residue levels. Seasonal variations in pesticide detection were observed during the study period (Figure 2(b)). Average levels per chemical family were higher in the rainy season than in the dry season except for carbamates in Dohou Lake where concentrations were higher in the dry season (Figure 2(c) and Figure 2(d)). Average concentrations were relatively higher in the rainy season than in the dry season for the majority of the active ingredients sought except for Aldicarb, Simazine and Monuron. The highest concentrations were measured when the first driest rains occurred shortly after pesticide application in early March. There are very different concentration profiles between the water sampling points. Aldicarb concentrations ranging from undetected to $37.5 \mu \mathrm{g} / \mathrm{L}$ were observed. According to the French standard, compliance with the quality standards for pesticides in surface fresh water intended for the production of drinking water is subject to the following joint verification of two conditions: the concentration of total pesticide residues must be less than $5 \mu \mathrm{g} / \mathrm{L}$ and the concentration of residues per substance must be less than $2 \mu \mathrm{g} / \mathrm{L}$ with the exception of four substances (aldrin, dieldrin, heptachlor and heptachlor epoxide) for which the standard is $0.03 \mu \mathrm{g} / \mathrm{L}$. Failure to comply with one or both of these conditions will result in non-compliance of the sampling point. The quality standards for surface water intended for drinking water are respected for $2 \%$ of the considered water points. Nearly $98 \%$ of the sampling points had at least one substance with an average concentration above the corresponding quality standard and $80 \%$ did not meet the total concentration standards. On average, three active ingredients were found with higher than standard levels in the samples.

\subsection{Health Risk Assessment}

The result of the various possible abatements calculated with the median and maximal values $(\mu \mathrm{g} / \mathrm{L})$ as well as the oral reference doses are recorded in Table 1. The results of the different abatements according to the two types of treatment showed values higher than $0.1 \mu \mathrm{g} / \mathrm{L}$ which is the European standard for an active ingredient.

\subsection{Health Risk Related to Water Consumption}

The HQ of the 7 pesticides considered is presented in Table 2. The HQ is less than 1 , considering the median values and the different abatements. The highest value in this case is $6.51 \times 10^{-1}$, which indicates that the lake water is relatively clean for consumption in this case. On the other hand, if we consider the maximum values of the raw water content for the calculation of the HQ, aldicarb, methyl-parathion and ethyl -parathion recorded values of HQ greater than 1 and the highest observed in the lake is for aldicarb in the case of children. Also, after $50 \%$ reduction in conventional treatment, aldicarb (1.53) also has the highest HQ value in the sample. These results indicate that aldicarb in the lake 
Table 1. Results of the various median and extreme reductions in the most highly-pollinated pesticides and their oral reference dose.

\begin{tabular}{cccccccc}
\hline Pesticides & Méd & Max & $\begin{array}{c}\mathbf{5 0 \%} \\
\text { abatement } \\
\text { (Méd) }\end{array}$ & $\begin{array}{c}\mathbf{7 5 \%} \\
\text { abatement } \\
\text { (Méd) }\end{array}$ & $\begin{array}{c}\mathbf{5 0 \%} \\
\text { abatement } \\
\text { (Max) }\end{array}$ & $\begin{array}{c}\mathbf{7 5 \%} \\
\text { abatement } \\
\text { (Max) }\end{array}$ & RfDo \\
\hline Aldicarb & 2 & 37.5 & 1 & 0.5 & 18.75 & 9.37 & 0.001 \\
Simazine & 2.35 & 18.2 & 1.17 & 0.58 & 9.1 & 4.85 & 0.005 \\
Monolinuron & 1.5 & 12.1 & 0.75 & 0.37 & 6.05 & 3.02 & 0.005 \\
Méthyl-Parathion & 2 & 4.31 & 1 & 0.5 & 2.15 & 1.08 & 0.00025 \\
Ethyl-Parathion & 2.06 & 4.64 & 1.05 & 0.52 & 2.32 & 1.16 & 0.00035 \\
Prometryn & 1.6 & 5 & 0.8 & 0.4 & 2.5 & 1.25 & 0.004 \\
Terbutryn & 1 & 4.85 & 0.5 & 0.25 & 2.42 & 1.22 & 0.001 \\
\hline
\end{tabular}

Med: median; Max: maximum.

Table 2. Non-carcinogenic risk of frequently detected pesticides according to two scenarios.

\begin{tabular}{|c|c|c|c|c|}
\hline \multirow{2}{*}{ Pesticides } & \multicolumn{2}{|c|}{ children } & \multicolumn{2}{|c|}{ Aldult } \\
\hline & $\mathrm{CDI}(\mathrm{mg} / \mathrm{Kg} / \mathrm{J})$ & HQ & $\mathrm{CDI}(\mathrm{mg} / \mathrm{Kg} / \mathrm{J})$ & HQ \\
\hline \multirow{6}{*}{ Aldicarb } & $1.63 \times 10^{-4 a}$ & $1.63 \times 10^{-1 \mathrm{a}}$ & $5.48 \times 10^{-5}$ & $5.48 \times 10^{-2}$ \\
\hline & $3.05 \times 10^{-3 b}$ & $3.05^{b}$ & $1,03 \times 10^{-3}$ & 1.03 \\
\hline & $8.14 \times 10^{-5 c}$ & $8.14 \times 10^{-2 c}$ & $2.74 \times 10^{-5}$ & $2.74 \times 10^{-2}$ \\
\hline & $4.07 \times 10^{-5 d}$ & $4.07 \times 10^{-2 \mathrm{~d}}$ & $1.37 \times 10^{-5}$ & $1.37 \times 10^{-2}$ \\
\hline & $1.53 \times 10^{-3 e}$ & $1.53^{\mathrm{e}}$ & $5.14 \times 10^{-4}$ & $5.14 \times 10^{-1}$ \\
\hline & $7.63 \times 10^{-4 f}$ & $7.63 \times 10^{-1 f}$ & $2.56 \times 10^{-4}$ & $2.56 \times 10^{-1}$ \\
\hline \multirow{6}{*}{ Simazine } & $1.91 \times 10^{-4}$ & $3.8 \times 10^{-2}$ & $6.44 \times 10^{-5}$ & $1.28 \times 10^{-2}$ \\
\hline & $1.48 \times 10^{-3}$ & $2.96 \times 10^{-1}$ & $4.99 \times 10^{-4}$ & $10^{-1}$ \\
\hline & $9.56 \times 10^{-5}$ & $1.9 \times 10^{-2}$ & $3.22 \times 10^{-5}$ & $6.44 \times 10^{-3}$ \\
\hline & $4.72 \times 10^{-5}$ & $9.4 \times 10^{-2}$ & $1.59 \times 10^{-5}$ & $3.18 \times 10^{-3}$ \\
\hline & $7.41 \times 10^{-4}$ & $1.48 \times 10^{-1}$ & $2.49 \times 10^{-4}$ & $4.98 \times 10^{-2}$ \\
\hline & $3.95 \times 10^{-4}$ & $7.90 \times 10^{-2}$ & $1.33 \times 10^{-4}$ & $2.66 \times 10^{-2}$ \\
\hline \multirow{6}{*}{ Monolinuron } & $1.22 \times 10^{-4}$ & $2.4 \times 10^{-2}$ & $4.11 \times 10^{-5}$ & $8.22 \times 10^{-3}$ \\
\hline & $9.85 \times 10^{-4}$ & $1.97 \times 10^{-1}$ & $3.32 \times 10^{-4}$ & $6.64 \times 10^{-2}$ \\
\hline & $6 \times 10 \times 10^{-5}$ & $1.2 \times 10^{-2}$ & $2.05 \times 10^{-5}$ & $4 \times 10 \times 10^{-3}$ \\
\hline & $3.04 \times 10^{-5}$ & $6.060 \times 10^{-3}$ & $1.02 \times 10^{-5}$ & $2.04 \times 10^{-3}$ \\
\hline & $4.92 \times 10^{-4}$ & $9.48 \times 10^{-2}$ & $1.66 \times 10^{-4}$ & $3.32 \times 10^{-2}$ \\
\hline & $2.43 \times 10^{-4}$ & $4.86 \times 10^{-2}$ & $8.28 \times 10^{-5}$ & $1.65 \times 10^{-2}$ \\
\hline \multirow{6}{*}{ Méthyl-Parathion } & $1.63 \times 10^{-4}$ & $6.51 \times 10^{-1}$ & $5.48 \times 10^{-5}$ & $2.19 \times 10^{-1}$ \\
\hline & $3.51 \times 10^{-4}$ & 1.400 & $1.18 \times 10^{-4}$ & $4.72 \times 10^{-1}$ \\
\hline & $8.14 \times 10^{-5}$ & $3.26 \times 10^{-1}$ & $2.74 \times 10^{-5}$ & $1 \times 10 \times 10^{-1}$ \\
\hline & $4.07 \times 10^{-5}$ & $1.63 \times 10^{-1}$ & $1.37 \times 10^{-5}$ & $5.48 \times 10^{-2}$ \\
\hline & $1.75 \times 10^{-4}$ & $7 \times 10^{-1}$ & $5.89 \times 10^{-5}$ & $2.35 \times 10^{-1}$ \\
\hline & $8.79 \times 10^{-5}$ & $3.51 \times 10^{-1}$ & $2.96 \times 10^{-5}$ & $1.18 \times 10^{-1}$ \\
\hline
\end{tabular}




\section{Continued}

\begin{tabular}{|c|c|c|c|c|}
\hline \multirow{6}{*}{ Ethyl-Parathion } & $1.68 \times 10^{-4}$ & $4.79 \times 10^{-1}$ & $5.60 \times 10^{-5}$ & $1.6 \times 10^{-1}$ \\
\hline & $3.78 \times 10^{-4}$ & 1.080 & $1.27 \times 10^{-4}$ & $3.63 \times 10^{-1}$ \\
\hline & $8.55 \times 10^{-5}$ & $2.44 \times 10^{-1}$ & $2.87 \times 10^{-5}$ & $8.20 \times 10^{-2}$ \\
\hline & $4.23 \times 10^{-5}$ & $1.20 \times 10^{-1}$ & $1,43 \times 10^{-5}$ & $4.08 \times 10^{-2}$ \\
\hline & $1.89 \times 10^{-4}$ & $5.40 \times 10^{-1}$ & $6.35 \times 10^{-5}$ & $1.81 \times 10^{-1}$ \\
\hline & $9.44 \times 10^{-5}$ & $2.69 \times 10^{-1}$ & $3.18 \times 10^{-5}$ & $9.08 \times 10^{-2}$ \\
\hline \multirow{6}{*}{ Prométryn } & $1.30 \times 10^{-4}$ & $3.2 \times 10^{-2}$ & $4.3 \times 10^{-5}$ & $1.1 \times 10^{-2}$ \\
\hline & $4.07 \times 10^{-4}$ & $1.02 \times 10^{-1}$ & $1.37 \times 10^{-4}$ & $3.4 \times 10^{-2}$ \\
\hline & $6.51 \times 10^{-5}$ & $1.6 \times 10^{-2}$ & $2.19 \times 10^{-5}$ & $5.47 \times 10^{-3}$ \\
\hline & $3.26 \times 10^{-5}$ & $8 \times 10^{-3}$ & $1.09 \times 10^{-5}$ & $2.72 \times 10^{-3}$ \\
\hline & $2.03 \times 10^{-4}$ & $5.07 \times 10^{-2}$ & $6.85 \times 10^{-5}$ & $1.71 \times 10^{-2}$ \\
\hline & $1.02 \times 10^{-4}$ & $2.55 \times 10^{-2}$ & $3.42 \times 10^{-5}$ & $8.55 \times 10^{-3}$ \\
\hline \multirow{6}{*}{ Terbutryn } & $8.14 \times 10^{-5}$ & $8.1 \times 10^{-2}$ & $2.7 \times 10^{-5}$ & $2.7 \times 10^{-2}$ \\
\hline & $3.95 \times 10^{-4}$ & $3.95 \times 10^{-1}$ & $1.33 \times 10^{-4}$ & $1.33 \times 10^{-2}$ \\
\hline & $4.07 \times 10^{-5}$ & $4.1 \times 10^{-2}$ & $2.74 \times 10^{-5}$ & $2.74 \times 10^{-3}$ \\
\hline & $2.03 \times 10^{-5}$ & $2.0 \times 10^{-2}$ & $1.37 \times 10^{-5}$ & $1.37 \times 10^{-2}$ \\
\hline & $1.97 \times 10^{-4}$ & $1.97 \times 10^{-1}$ & $6.63 \times 10^{-5}$ & $6.63 \times 10^{-2}$ \\
\hline & $9.93 \times 10^{-5}$ & $9.93 \times 10^{-2}$ & $3.34 \times 10^{-5}$ & $3.34 \times 10^{-2}$ \\
\hline \multirow{6}{*}{\multicolumn{2}{|c|}{$\mathrm{HQ} s=\Sigma \mathrm{HQi}$}} & $1.468^{\mathrm{a}}$ & & 0.4928 \\
\hline & & $6.518^{b}$ & & 2.079 \\
\hline & & $0.739^{c}$ & & 0.2381 \\
\hline & & $0.4517^{\mathrm{d}}$ & & 0.1309 \\
\hline & & $3.260^{\mathrm{e}}$ & & 1.096 \\
\hline & & $1.635^{\mathrm{f}}$ & & 0.5498 \\
\hline
\end{tabular}

${ }^{a}$ Non-carcinogenic hazard quotient (child, median concentration); ${ }^{b}$ Non-carcinogenic hazard quotient (child, extreme concentration); 'Non-carcinogenic hazard quotient (child, median concentration after 50\% abatement); ${ }^{\mathrm{d}}$ Non-carcinogenic hazard quotient (child, median concentration after $75 \%$ abatement); ${ }^{\mathrm{e}}$ Non-carcinogenic risk quotient (child, extreme concentration after $50 \%$ abatement); ${ }^{\mathrm{f}}$ Non-carcinogenic hazard quotient (child, extreme concentration after $75 \%$ abatement).

poses a potential risk to children through the consumption of raw water before and after $50 \%$ reduction. On the other hand, the potential risk of exposure through ingestion after a $75 \%$ abatement is low. The HQ estimates for each pesticide by ingestion when considering the median value follows the order of methyl parathion $>$ ethyl parathion $>$ aldicarb $>$ Terbutryne $>$ Simazine $>$ prometryne $>$ Monolinuron. Regarding the case of the risk assessment for adults when extreme concentrations are taken into account, only aldicarb has HQ greater than 1 suggesting a risk for this class of person. However, the potential risk is low after at least $50 \%$ of abatement for adults. The cumulative risk potentials (HQs) posed by several pesticides after a $50 \%$ and $75 \%$ reduction are respectively 3260 and 1635 when extreme concentrations are taken into account for children 
(Table 2). For adults, only the cumulative risk potential (HQs) posed by several pesticides after $50 \%$ abatement is greater than 1 . The cumulative risk assessment was calculated using a simplified additive approach by summing the individual HQs posed by each pesticide; the effects of synergistic, antagonistic or other interactions have not been taken into account. The non-cancer risk of children is higher than the potential risk for adults.

\subsection{Heavy Metals Index}

The HPI and HEI values for 28 water samples were calculated and these mean indices of heavy metal pollution per station were shown in Figure 3. The average heavy metal pollution index (HPI) for station 7 (187) was above the value of critical limit 100. No significant spatial variation in water quality was observed as illustrated by the variation of HPI (Figure 3(a)). The heavy metals evaluation index (HEI) is used to discriminate the criteria of the different pollution indices. The HEI criteria for surface water samples are therefore classified as low (HEI < $40)$, medium $(\mathrm{HEI}=40-80)$ and high $(\mathrm{HEI}>80)$. It is observed that surface

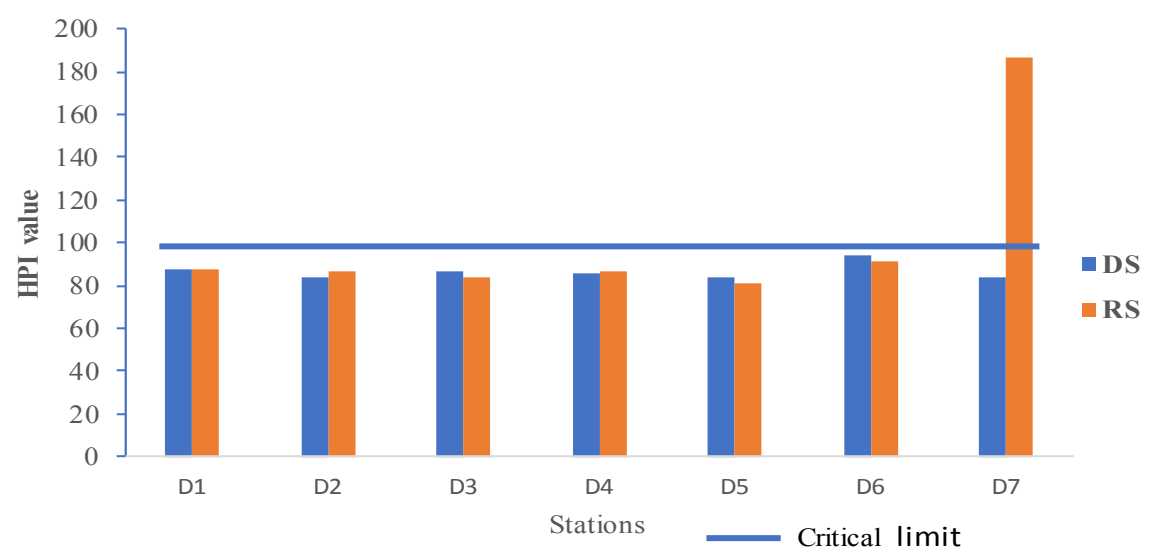

(a)

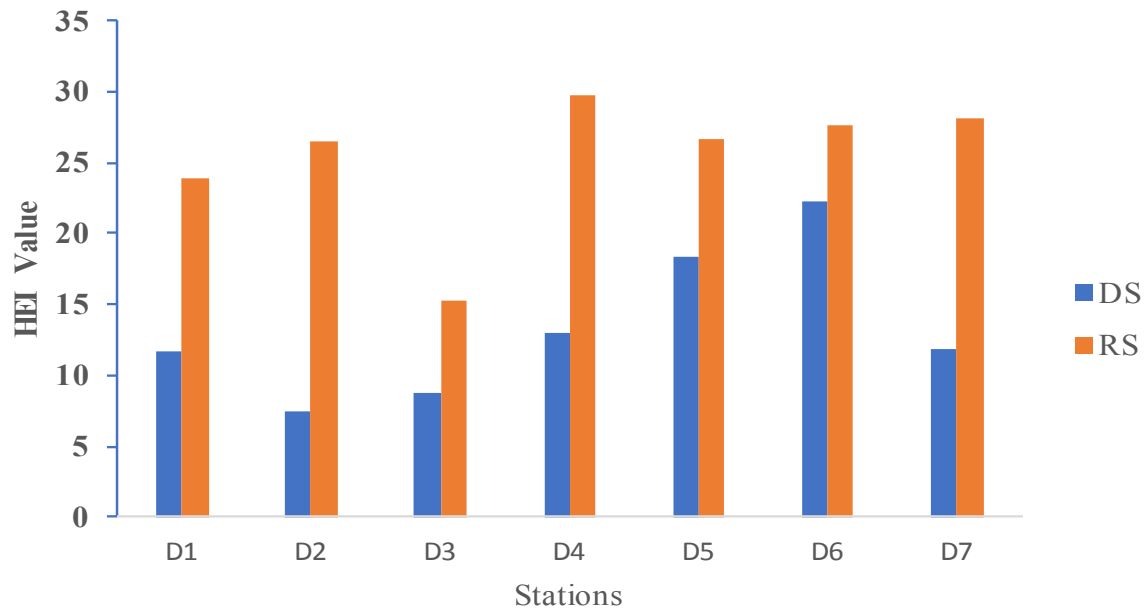

(b)

Figure 3. Spatial and temporal variation in surface water quality index values in the study area. RS: Rainy Season; DS: Dry Season, Guide levels: 100. 
water in the study area has a low pollution level for heavy metals. The HEI index reveals a significant seasonal variation $(\mathrm{p}<0.001)$ in water quality between the dry season and the rainy season (Figure $3(\mathrm{~b})$ ). In general, the dry season recorded significantly lower heavy metal concentrations $(\mathrm{p}<0.05)$ than in the rainy seasons.

\subsection{Overall Water Quality Index}

The spatial distribution of water quality data is shown in Table 3 for all parameters studied. The $\mathrm{pH}$ of Dohou Lake was generally acidic. The average $\mathrm{pH}$ value was below the acceptable standard for drinking water. Dissolved oxygen (DO) is an important parameter in the assessment of water quality for aquatic life and for consumption. Mean values of DO at all monitoring points were within the quality criteria for aquatic fitness and for drinking water production. The lowest mean DO concentration was recorded at Station 7. Biological oxygen demand has a great advantage in estimating organic matter pollution. The average value of $\mathrm{BOD}_{5}$ is higher than the acceptable standard for drinking water production FQWS. Station 7 recorded the highest average concentration of $\mathrm{BOD}_{5}$ in the study period. For all forms of nitrogen in Dohou Lake, nitrite has the lowest concentrations. However, some values are beyond the limit required for aquatic fitness. All nitrogen compounds comply with the drinking water quality standard except for total nitrogen. Some values of the different parameters were higher than the recommendations for aquatic life. For forms of phosphorus (orthophosphate and total phosphorus) evaluated in water, the average grade of orthophosphate remained in compliance with both standards (FQWS, WHO). On the other hand, the average total phosphorus content exceeds the permissible concentration for water intended for the production of drinking water and the protection of aquatic life. All forms of nitrogen and orthophosphate measured were correlated $(\mathrm{r}=0.69-0.93, \mathrm{n}=48, \mathrm{p}<0.01)$. Microbiological analyzes show the presence of fecal coliform bacteria (E. coli) and enterococci in the waters of Dohou Lake (Table 3). These bacteria are good indicators of recent faecal contaminations. All sampling points recorded levels above WHO standards and some were well in aquatic life guidelines and some exceeded criteria for drinking water production. The most commonly detected pesticides (aldicarb, simazine and monolinuron) have been incorporated into the overall assessment of water quality. Stations D3 and D4 recorded the highest average levels of pesticides (aldicarb, simazine and monolinuron). The mean concentrations of aldicarb per station in the study period (Table 3) range from $0.65 \pm 0.94 \mu \mathrm{g} / \mathrm{L}$ to $10.39 \pm$ $18.11 \mu \mathrm{g} / \mathrm{L}$ for lake water and exceed the allowable concentration for drinking water production and the protection of aquatic life at certain sampling points. This is the same for simazine and monolinuron pesticides with mean concentrations ranging from $1.04 \pm 1.29$ to $6.05 \pm 7.58 \mu \mathrm{g} / \mathrm{L}$ and from $0.35 \pm 0.49$ to $4.21 \pm$ $3.4 \mu \mathrm{g} / \mathrm{L}$, respectively. The average concentrations per station of $\mathrm{Hg}, \mathrm{Cd}, \mathrm{Pb}, \mathrm{As}$, $\mathrm{Cu}, \mathrm{Zn}, \mathrm{Mn}$ and $\mathrm{Fe}$ in Dohou Lake ranged respectively by $0.36 \pm 0.30-0.71 \pm$ $0.39 ; 0.05 \pm 0.03-0.36 \pm 0.45 ; 1.74 \pm 1.83-7.52 \pm 3.45 ; 0.85 \pm 1.10-9.40 \pm 5.34$; 
Table 3. Basic statistics of physical, chemical and microbial variables in Dohou Lake.

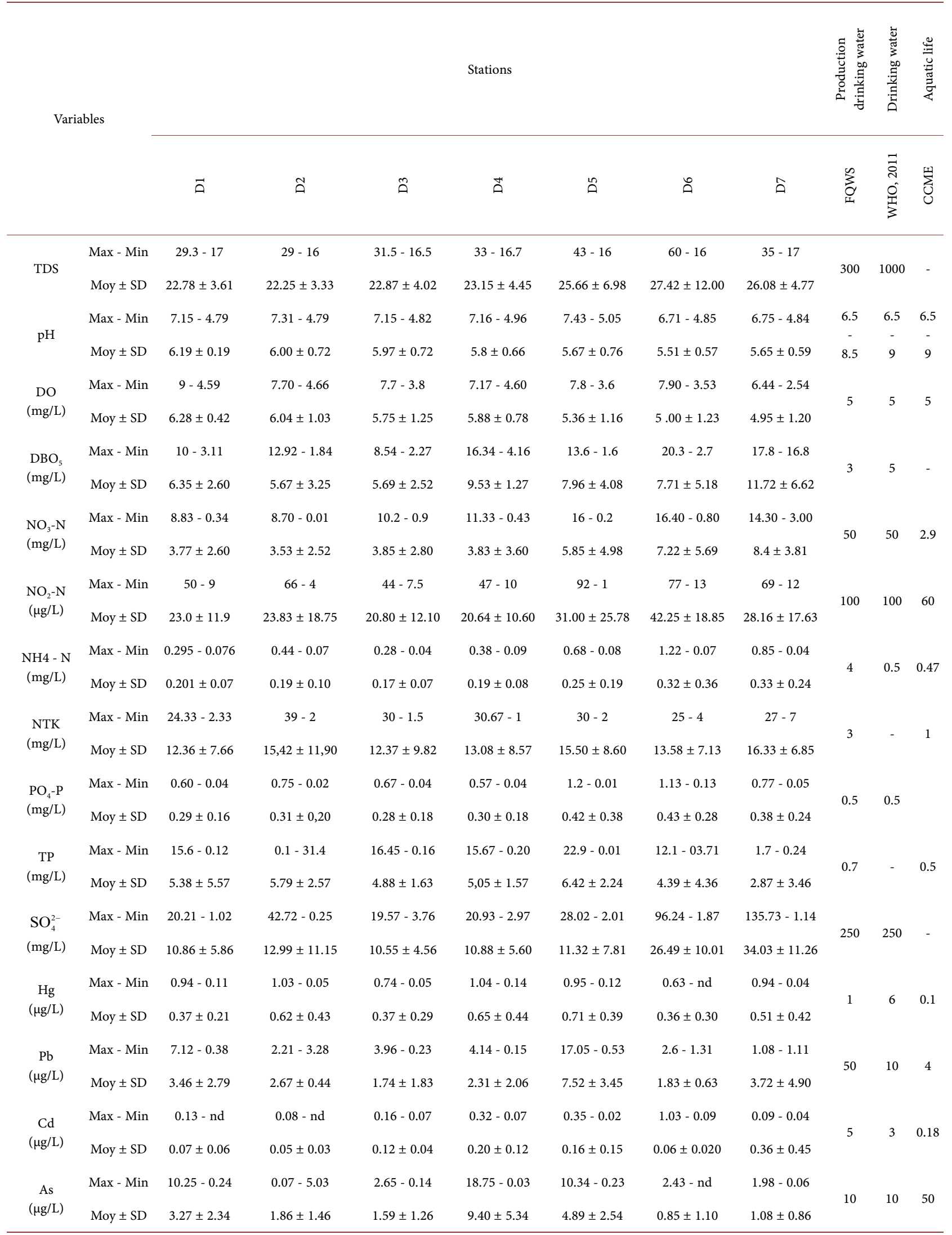




\section{Continued}

\begin{tabular}{|c|c|c|c|c|c|c|c|c|c|c|c|}
\hline \multirow{2}{*}{$\begin{array}{c}\mathrm{Cu} \\
(\mu \mathrm{g} / \mathrm{L})\end{array}$} & Max - Min & $3.13-0.23$ & $3.46-1.25$ & $2.23-0.99$ & $2.8-0.78$ & $3.78-2.07$ & $2.34-1.50$ & $3.98-1.89$ & \multirow{2}{*}{50} & \multirow{2}{*}{2000} & \multirow{2}{*}{2} \\
\hline & Moy \pm SD & $1.63 \pm 1.29$ & $2.38 \pm 0.90$ & $1.89 \pm 0.60$ & $1.70 \pm 0.88$ & $2.87 \pm 0.78$ & $1.86 \pm 0.40$ & $2.81 \pm 0.97$ & & & \\
\hline $\begin{array}{c}\mathrm{Mn} \\
(\mu \mathrm{g} / \mathrm{L})\end{array}$ & Moy \pm SD & $2.65 \pm 0.90$ & $1.58 \pm 0.58$ & $2.20 \pm 1.06$ & $3.49 \pm 0.86$ & $3.02 \pm 1.73$ & $2.77 \pm 0.66$ & $2.93 \pm 1.12$ & & 1000 & - \\
\hline \multirow{2}{*}{$\begin{array}{c}\mathrm{Zn} \\
(\mu \mathrm{g} / \mathrm{L})\end{array}$} & Max - Min & $3.02-0.58$ & $0.30-2.12$ & $2.24-0.85$ & $9.25-0.65$ & $4.09-0.17$ & $2.14-0.54$ & $2.21-0.21$ & \multirow{2}{*}{5000} & & \multirow{2}{*}{30} \\
\hline & Moy \pm SD & $1.56 \pm 1.13$ & $1.08 \pm 0.75$ & $1.37 \pm 0.60$ & $3.48 \pm 4.02$ & $2.46 \pm 1.74$ & $1.7 \pm 0.76$ & $1.60 \pm 0.91$ & & & \\
\hline $\mathrm{Fe}$ & Max - Min & $4273-1032$ & $5432-1064$ & $2548-995$ & $6621-1288$ & $4915-1530$ & $6036-2298$ & $4906-1540$ & \multirow{2}{*}{300} & \multirow{2}{*}{200} & \multirow{2}{*}{300} \\
\hline$(\mu \mathrm{g} / \mathrm{L})$ & Moy \pm SD & $2985 \pm 1399.56$ & $2896.25 \pm 2172.24$ & $2066.50 \pm 721.14$ & $3768.0 \pm 2231.2$ & $3351.25 \pm 149.90$ & $4663.5 \pm 1.78$ & $3235.24 \pm 1.55$ & & & \\
\hline $\begin{array}{c}\text { E. Coli } \\
\text { CFU/100mL }\end{array}$ & Max - Min & $1315-960$ & $1000-210$ & $160-130$ & $370-200$ & $550-200$ & $1650-1180$ & $170-120$ & 200 & 0 & 400 \\
\hline \multirow{2}{*}{$\begin{array}{l}\text { Entérocoques } \\
\text { CFU/100mL }\end{array}$} & Max - Min & $1140-420$ & $970-250$ & $550-100$ & $320-70$ & $460-150$ & $980-20$ & $250-240$ & \multirow{2}{*}{100} & \multirow{2}{*}{0} & \multirow{2}{*}{400} \\
\hline & Moy \pm SD & $790.00 \pm 295.97$ & $502.50 \pm 332.60$ & $322.5 \pm 195.00$ & $175.00 \pm 113.78$ & $247.5 \pm 146.6$ & $360.00 \pm 64.93$ & $460.00 \pm 241.24$ & & & \\
\hline \multirow{2}{*}{$\begin{array}{l}\text { Aldicarbe } \\
(\mu \mathrm{g} / \mathrm{L})\end{array}$} & Max - Min & 13-nd & $11.2-\mathrm{nd}$ & $37.50-0.08$ & $36.5-0.8$ & $8.60-0.02$ & 2-nd & 2-nd & \multirow{2}{*}{2} & \multirow{2}{*}{0.1} & \multirow{2}{*}{5} \\
\hline & Moy \pm SD & $6.25 \pm 5.56$ & $3.70 \pm 5.16$ & $10.39 \pm 18.11$ & $9.05 \pm 8.12$ & $3.15 \pm 3.75$ & $0.90 \pm 0.82$ & $0.65 \pm 0.94$ & & & \\
\hline \multirow{2}{*}{$\begin{array}{l}\text { Simazine } \\
(\mu \mathrm{g} / \mathrm{L})\end{array}$} & Max - Min & 4 -nd & 2.35-nd & 18.2-nd & 16-nd & $17-0.01$ & $6.0-0.8$ & $2.87-\mathrm{nd}$ & \multirow{2}{*}{2} & \multirow{2}{*}{0.1} & \multirow{2}{*}{5} \\
\hline & Moy \pm SD & $2.71 \pm 1.83$ & $1.08 \pm 1.26$ & $4.81 \pm 4.46$ & $3.56 \pm 2.20$ & $6.05 \pm 7.58$ & $2.56 \pm 2.40$ & $1.04 \pm 1.29$ & & & \\
\hline \multirow{2}{*}{$\begin{array}{l}\text { Monolinuron } \\
(\mu \mathrm{g} / \mathrm{L})\end{array}$} & Max - Min & 4-nd & 1.4-nd & 12.10-nd & 11.30 -nd & 0.9 -nd & 6.4-nd & $8.57-\mathrm{nd}$ & \multirow{2}{*}{2} & \multirow{2}{*}{0.1} & \multirow{2}{*}{5} \\
\hline & Moy \pm SD & $1.75 \pm 2.06$ & $0.35 \pm 0.49$ & $3.03 \pm 3.02$ & $4.21 \pm 3.4$ & $0.40 \pm 0.47$ & $1.60 \pm 3.20$ & $2.84 \pm 3.90$ & & & \\
\hline
\end{tabular}

Nd: No detected, SD: Standard derivation.

$1.63 \pm 1.29-2.87 \pm 0.78 ; 1.08 \pm 0.75-3.48 \pm 4.02 ; 1.58 \pm 0.58-3.49 \pm 0.86$ and $2985 \pm 1399.56-4663.5 \pm 1.78$. Generally, the highest concentrations of heavy metals were found at Station 5. Iron is one of the most common metals in nature. Fe concentrations exceeded the recommendations in most of the samples studied (Table 3). In addition, Hg concentrations in the lake water exceeded the recommended limits for aquatic life at all stations. All sampling points recorded levels of $\mathrm{Cd}, \mathrm{Pb}, \mathrm{Cu}$ and As below WHO standards and some were above guidelines for aquatic life and some exceeded the criteria for drinking water production. The WHO drinking water quality indices and its ability to protect aquatic life (CMME) remained consistently in the poor class (33.74 - 38.71; 32.81 42.45 , respectively) on all sampling stations (Figure 4) with lower scores than others. Station 5 recorded the lowest score. The index trend for aquatic life and quality according to WHO decreases as one moves away from the dike (D1 to D5). In addition, the quality index for drinking water production recorded the highest values (51.04 - 56.48) that the first mentioned above but remains in the marginal class (Table 4).

\section{Discussion}

\subsection{Pesticides}

The large variability in pesticide concentrations at Dohou Lake can be partly 
Table 4. Calculated values of Dohou lake water quality indices.

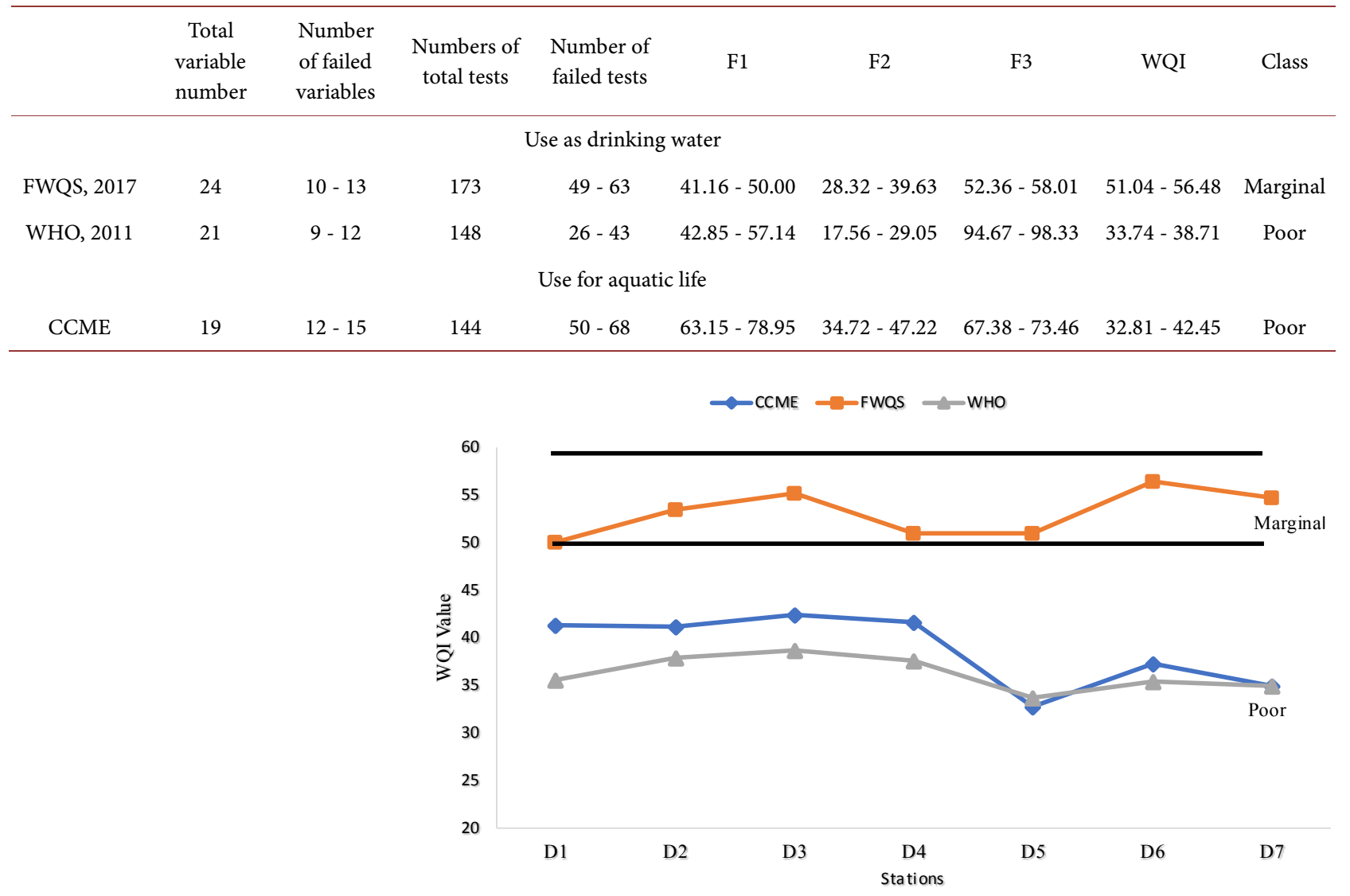

Figure 4. Spatial evolution of water quality according to WHO, FWQS and CCME.

explained by variations in the physicochemical characteristics of the environment, which can be very important from one point to another and from one period to another. Season-to-season variation would depend on precipitation that controls soil erosion and suspended solids [29]. In addition to Duékoué, many natural factors favor runoff (very pronounced relief, violent and frequent rainfall events) and contribute to amplifying the potential risk of pesticide transfer to the aquatic environment, due in particular to the very close proximity between cultivated plots and the aquatic environment. Average concentrations were relatively higher in the rainy season than in the dry season for the majority of the active ingredients sought except for aldicarb, simazine and monuron. This may indicate that surface water pollution is not persistent and that the rate of pesticide degradation in the water reservoir can be rapid. Similar results have been reported by several authors [30] [31] who found higher values of aldicarb and simazine in the dry season. In contrast, some pesticides, such as prometryn and monolinuron, were detected at almost constant concentrations for extended periods. This could indicate that these pesticides are likely to persist in surface water and may have a potential risk impact to the aquatic ecosystem. The high solubility $\left(6 \mathrm{~g} / \mathrm{L}\right.$ at $\left.20^{\circ} \mathrm{C}\right)$ of aldicarb, its low affinity for many soils $(\operatorname{logKd}<4$ $\mathrm{L} / \mathrm{kg}$ ) and its popularity with farmers, could explain its frequency of very high 
detections observed in this study [32]. Indeed, the cultures made on the edges of the water reservoir are very sensitive to the attacks of several insects and pathogens at this time. Thus, different active ingredients are used alone or in a mixture to control crop pests. Also, the carbamate molecules have a high potential for leaching because of their low adsorption capacity, their intermediate DT50 and their relative solubility in water, hence their relative low rainfall season content in surface water [33]. The highest concentrations were measured when the first driest rains occurred shortly after pesticide application in early March, when field work began with the use of herbicides. Much of the lake's pollution during this period is due to the fact that, during surface water runoff and erosion of soil particles, pesticide residues are transported from agricultural soils to lakes without obscuring the leaf leaching of the soil pesticides by the rain [34]. For simazine, its high dry season content indicates significant use at the site studied during this period. Also, the high content of simazine and monuron in the dry season reflects the fact that water contamination by pesticides is often an irregular phenomenon [35]. In contrast, substituted urea and organophosphorus (mostly) have high retention potential (high $\mathrm{K}_{\mathrm{OC}}$ ) and are therefore more transported by runoff. Thus, in case of torrential rain, one can attend a more or less important increase of their concentration because of the very important runoff. Herbicides were the most frequently detected contaminants. This would be related to both the properties of these substances (DT50, solubility in water) and the characteristics of their use which are related to the tonnage marketed, but also to the period of application and the dose of use. The large use of triazines and the similarity of their physicochemical properties such as water solubility, high polarity, low degree of adsorption in soils and high persistence, could be the cause of the frequent occurrence of these chemicals and their metabolites in surface water in rainy seasons. The mixed trend in the evolution of dry season levels is likely due to the influence of chemical structures within the same family. In fact, although no overall ranking could be established for the degree of degradability, it appears that urea and sulfonylurea degrade more rapidly than molecules belonging to other families. The average pesticide levels in a sample are much higher than the guideline value of $0.50 \mu \mathrm{g} / \mathrm{L}$. This strong presence of phytosanitary products in the waters is explained by the action of rainwater that leaches the substances spread in plantations to the lake. It is also explained by the action of the wind. In fact, during the spraying of the plantations bordering the lake and the tributary river, polluted air laden with pesticide particles ends up in the waters. These pesticide concentrations are likely to pose a quality problem for water intended for human consumption. In all cases, the total concentration of the compounds in each sampling point was greater than $0.5 \mu \mathrm{g} / \mathrm{l}$, which corresponds to the limit set by the European Union for the presence of pesticide in water drinks [20]. Also, a reduction of $75 \%$ on the median value gave results higher than the required standard $(0.1 \mu \mathrm{g} / \mathrm{L})$. This testifies to the poor quality of the water. The non-carcinogenic risks for adults and children calculated showed a worrying result after a $50 \%$ abatement for these two age 
groups. On the other hand, after treatment with $75 \%$ abatement the potential risk becomes low. It would be justifiable to use a filtration treatment accompanied by ozone treatment. In addition, the cumulative risk (HQs) is greater than unity regardless of the type of treatment which raises fears of potential adverse effects due to long-term pesticide accumulation. Children were at higher risk than adults due to lower Weight [36] [37]. Similar results were reported by [27] and [23] in their study.

\subsection{Heavy Metals Index}

The waters of Dohou Lake have a low level of pollution related to heavy metals. HEI values showed significant seasonal variation, while HPI values did not show any significant variation. The difference in trace element levels observed between stations may be due to the nature of the releases at these stations. Stations 5 and 7 that are more subject to human influence have high concentrations [15]. Station 5 receives a portion of wastewater from Duékoué town and discharges from the activities of auto mechanics. The heavy loads in metallic elements are recorded in rainy season as illustrated by the seasonal variation of HEI values. Similar findings are obtained from the recent studies conducted in various regions of the world [14] [38]. The concentrations recorded during the dry season are mainly due to the input of sewage from the lakeside houses and the resuspension of the particulate material due to the release of sediments which would enrich the water column with metallic elements. Indeed, these metal pollutants pass into the water column when conditions are favorable, thus causing adverse effects on water quality and aquatic life. These high levels of metallic elements raise the problem of the bioavailability of these elements.

\subsection{Overall Water Quality Index}

The average $\mathrm{pH}$ is lower than WHO standards for drinking water, the drinking water production guideline (FWQS) and the protection of aquatic life (CMME). $\mathrm{PH}$ values between 6.5 and 8.5 generally indicate good quality water [39]. Therefore, this resource isn't good quality because the efficiency of chlorine disinfection is minimized when the $\mathrm{pH}$ is outside this range [40]. The DO depends on many factors, including in organic matter, temperature, turbulence and water velocity. The lowest mean DO concentration was recorded at Station 7. This situation is attributable to the position of this station, which is the spillway of the water treatment plant. Indeed, this open and shallower station allows more heat exchange with the atmosphere because a warmer water decreases the dissolved oxygen in saturation, leading to a lower content of DO. In addition to reducing DO saturation, a higher water temperature increases $\mathrm{BOD}_{5}$ by accelerating the decomposition of organic matter which could explain the high $\mathrm{BOD}_{5}$ content at this station. Notably, all $\mathrm{BOD}_{5}$ values were not in compliance with drinking water guidelines. The high organic matter content could be attributed to the presence of greater forest cover and slash-and-burn agriculture that promotes organic carbon input to surface water on the watershed [41]. The decomposition of 
organic matter causes a large consumption of dissolved oxygen and is accompanied by a deoxygenation of the waters of Lake Dohou hence the low levels of DO recorded. It should be noted that the concentrations of nitrogen and phosphorus compounds in the lake depend mainly on the sources of pollution and the different chemical reactions that could be attributed to the processes of denitrification, nitrification, biogenic assimilation and burial in sediments. Some nutrient values are beyond the limit required for aquatic fitness, and this fluctuation reflects the influx of anthropogenic effluents into Dohou Lake. All these variations result in changes in biodiversity and disturbances of phytoplankton biomass. Microbiological analyzes show the presence of fecal coliform bacteria (E. coli) and enterococci in Dohou Lake waters above the required standards indicating an anthropogenic influence. This indicates that water is contaminated by fecal contamination and should not be consumed without treatment [42]. All sampling points recorded levels of $\mathrm{Cd}, \mathrm{Pb}, \mathrm{Cu}$ and As below the WHO standards and some were above guideline for aquatic life (CMME) and sometimes exceeded the criteria for water drinking production. The metallic trace elements come mainly from the erosion of rocks, soils and sediments where they are present in their natural state. Most of them come from artisanal quarrying activities on the banks of the watercourse and wastewater. Their anthropic origins are numerous. They are derived from the leaching of plant protection products and fertilizers used in plantations. Indeed, the content of metals in water bodies depends on many factors such as weathering, climate, soil type, $\mathrm{pH}$, redox potential and dilution capacity. Fe concentrations exceeded the guidelines in most of the samples studied and $\mathrm{Hg}$ concentrations in the lake water exceeded the aquatic guideline limits at all stations. Our results corroborate those of [43] who also found grades exceeding the recommendations. Activities in the study area could explain this state of affairs. In fact, the lake reviews the urban waste and on its borders are stored the carcasses of abandoned cars. In addition, crops located in the watershed influence the quality of its water by leaching plant protection products and fertilizers that contain trace metal elements. The effect of iron on aquatic organisms is primarily indirect; Fe contamination affects species diversity and abundance of benthic fish and invertebrates [44]. Also, Fe is classified as a secondary contaminant of drinking water but it can cause an unpleasant taste, smell, corrosion or staining problems [43]. Lake WQI results show no significant spatial variation $(p>0.05)$, reflecting near constant water quality due to the small size of the watercourse. The few fluctuations observed would be attributable to the combination of natural and human activities. The three indices show that the water quality of Dohou Lake is deteriorating. Contaminants, mainly pesticides, microbiological parameters and organic matter have an impact on water quality and have reduced its self-purification capacity and have also affected the water quality of the lake for many purposes.

\section{Conclusion}

This study consisted of assessing the current water quality of Dohou Lake used 
for water production through several physico-chemical, microbiological and micropollutant analyses using water quality indices. Based on the possible water treatment abatement results for pesticides, a human health risk assessment was conducted for adults and children. Seasonal variations in measured pesticide and heavy metal concentrations were observed in the lake and remained low during the dry season. Total metal concentrations and environmental indices (HPI and HEI) indicated that lake water samples were weakly contaminated by metals. The various quality indices (WQI) calculated indicate that the water quality of the lake is deteriorating and has increased overall from 56 (marginal) to 32 (Poor), where the low values of all WQIs have been recorded at the same station 5. The main contributors to the reduction of the self-cleaning capacity of the lake were pesticides, organic matter and microbiological parameters. Estimates of cumulative risk quotient (HQs) after abatement for frequently identified pesticides were above acceptable risk values. The inclusion of microbiological parameter data and pesticides in the WQI revealed the exact quality of the lake. Therefore, the inclusion of these water parameters is paramount to having a complete form of unbiased data. The situation deserves the attention of policy makers and requires taking a number of measures to rationalize the use of plant protection products and thus limit the risks of exposure.

\section{Conflicts of Interest}

The authors declare no conflict of interest.

\section{References}

[1] Ministère de l'Agriculture et des Ressources Animales (MINAGRA), Direction des Statistiques, de la Documentation et de l'Informatique (DSDI), 2001-Recensement National de l'Agriculture. Abidjan, Côte d'Ivoire, 57 p.

[2] Chapagain, T. and Raizada, M.N. (2017) Agronomic Challenges and Opportunities for Smallholder Terrace Agriculture in Developing Countries. Frontiers in Plant Science, 8, 331. https://doi.org/10.3389/fpls.2017.00331

[3] Antle, J.M., Basso, B., Conant, R.T., Godfray, H.C.J., Jones, J.W., Herrero, M. and Wheeler, T.R. (2017) Towards a New Generation of Agricultural System Data, Models and Knowledge Products: Design and Improvement. Agricultural Systems, 155, 255-268. https://doi.org/10.1016/j.agsy.2016.10.002

[4] Adu-Kumi, S., Kawano, M., Shiki, Y., Yeboah, P.O., Carboo, D., Pwamang, J. and Morita, M. (2010) Organochlorine Pesticides (OCPs), Dioxin-Like Polychlorinated Biphenyls (dl-PCBs), Polychlorinated Dibenzo-p-Dioxins and Polychlorinated Dibenzofurans (PCDD/Fs) in Edible Fish from Lake Volta, Lake Bosumtwi and Weija Lake in Ghana. Chemosphere, 81, 675-684. https://doi.org/10.1016/j.chemosphere.2010.08.018

[5] FAO (2011) La pratique de la gestion durable des terres. Directives et bonnes pratiques pour l'Afrique subsaharienne. FAO, Rome, $249 \mathrm{p}$.

[6] Dziuban, E.J., Liang, J.L., Craun, G.F., Hill, V. and Yu, P.A. (2006) Surveillance for Waterborne Disease and Outbreaks Associated with Recreational Water, United States, 2003-2004. MMWR Surveillance Summaries, 55, 1-30.

[7] El Mostafa, H. (2006) Effet des rejets liquides domestiques et industriels sur la qua- 
lité des eaux souterraines au nord de la ville de Settat (Maroc). Bulletin de P institut scientifique, Rabat (Maroc), Section sciences de la vie, No. 28, 61-71.

[8] Julie, W. (2008) Développement d'un indicateur d'exposition des eaux de surface aux pertes de pesticides : A l'échelle du bassin versant. Planète et Univers [Physics]. Institut National Polytechnique de Lorraine-UMR Nancy-Université-INRA Agronomie et Environnement Nancy-Colmar, 198 p.

[9] Stehle, S. and Schulz, R. (2015) Agricultural Insecticides Threaten Surface Waters at the Global Scale. Proceedings of the National Academy of Sciences, 112, 5750-5755. https://doi.org/10.1073/pnas.1500232112

[10] Aljer, L. (2017) Biodiversity Is Key for More Variety for Better Society. Biodiversity International Journal, 1, 1-4. https://doi.org/10.15406/bij.2017.01.00002

[11] Aljer, L (2018) Exploratory Study of Xanthine Dehydrogenase (XD) Accumulation in Chicks' Organs: XD Natures and Its Inhibitory Activities. Journal of Advances in Biology, 11, 2269-2276. https://doi.org/10.24297/jab.v11i0.7825

[12] Dapam, I.L., Ibrahim, E.G. and Dodo, J.D. (2018) Heavy Metal Speciation Study of Water and Bottom Sediments from River Wujam in Chip District of Pankshin Local Government Area, Plateau State, Nigeria. Environmental Science and Pollution Research, 4, 242-245. https://doi.org/10.30799/jespr.119.18040102

[13] Nimic, D.A. and Moore, J.N. (1991) Prediction of Water-Soluble Metal Concentrations in Fluvially Deposited Tailings Sediments, Upper Clark Fork Valley, Montana, U.S.A. Applied Geochemistry, 6, 635-646. https://doi.org/10.1016/0883-2927(91)90074-Y

[14] Bhuiyan, M.A.H., Bodrud-Doza, M., Towfiqul Islam, A.R., Rakib, M., Safiur Rahman, M.A.M. and Ramanathan, A.L. (2016) Assessment of Groundwater Quality of Lakshimpur District of Bangladesh Using Water Quality Indices, Geostatistical Methods, and Multivariate Analysis. Environmental Earth Sciences, 75, 1020. https://doi.org/10.1007/s12665-016-5823-y

[15] Kouamé, K.B., Konan, K., Attoungbre, K.S., Konan, K.F., Boussou, K.C. and Kouamé, K.M. (2019) Qualitative Assessment and Typology of the Water Resource Used for the Production of Drinking Water in Duékoué, Western Côte d'Ivoire. Journal of Geoscience and Environment Protection, 7, 212-231. https://doi.org/10.4236/gep.2019.75017

[16] Belkhiri, L., Ammar, T. and Lotfi, M. (2018) Assessment of Heavy Metals Contamination in Groundwater: A Case Study of the South of Setif Area, East Algeria. https://doi.org/10.5772/intechopen.75734

[17] Prasad, B. and Jaiprakas, K.C. (1999) Evaluation of Heavy Metals in Ground Water near Mining Area and Development of Heavy Metal Pollution Index. Journal of Environmental Science and Health, Part A, 34, 91-102. https://doi.org/10.1080/10934529909376825

[18] Edet, A.E. and Offiong, O.E. (2002) Evaluation of Water Quality Pollution Indices for Heavy Metal Contamination Monitoring. A Study Case from Akpabuyo-Odukpani Area, Lower Cross River Basin (Southeastern Nigeria). GeoJournal, 5, 295-304. https://doi.org/10.1023/B:GEJO.0000007250.92458.de

[19] CCME (Canadian Council of Ministers of the Environment) (2001) Canadian Water Quality Guidelines for the Protection of Aquatic Life: CCME Water Quality Index 1.0, User's Manual. In: Canadian Environmental Quality Guidelines, 1999, Canadian Council of Ministers of the Environment, Winnipeg.

[20] FWQS (French Drinking Water Production Quality Standards) (2017) Ministry of Health and Solidarities. Decree of 04/08/2017 Amending Several Decrees Relating to 
Water and Reference Quality of Raw Water and Water for Consumption Number R.1321-38 to R.1321-41.

[21] WHO (World Health Organization) (2011) Guidelines for Drinking Water Quality. 4th Edition, WHO, Geneva, 564 p.

[22] Hu, Y., Qi, S., Zhang, J., Tan, L., Zhang, J., Wang, Y. and Yuan, D. (2011) Assessment of Organochlorine Pesticides Contamination in Underground Rivers in Chongqing, Southwest China. Journal of Geochemical Exploration, 111, 47-55. https://doi.org/10.1016/j.gexplo.2011.07.006

[23] Papadakis, N.E., Vryzas, Z., Kotopoulou, A., Kintzikoglou, K., Makris, C.K. and Papadopoulou-Mourkidou, E. (2015) A Pesticide Monitoring Survey in Rivers and Lakes of Northern Greece and Its Human and Ecotoxicological Risk Assessment. Ecotoxicology and Environmental Safety, 116, 1-9. https://doi.org/10.1016/j.ecoenv.2015.02.033

[24] IRIS (Integrated Risk Information System) US Environmental Protection Agency, 2010 Cincinnati, OH. http://www.epa.gov/iris

[25] USEPA (2010) Regional Screening Level (RSL) Tapwater Supporting Table. https://epa-prgs.ornl.gov/chemicals/download/master_sl_table_run_JUN2011.pdf

[26] Edder, P., Orteilli, D. and Ramseier, S. (2006) Métaux et micropolluants organiques. Rapports de la commission internationale pour la protection des eaux du Léman contre la pollution, Campagne 2005, 65-87.

[27] Shi,W., Zhang, F.X., Zhang, X.W., Su, G.Y., Wei, S., Liu, H.L., Cheng, S.P. and Yu, H.X. (2011) Identification of Trace Organic Pollutants in Freshwater Sources in Eastern Chinand Estimation of Their Associated Human Health Risks. Ecotoxicology, 20, 1099-1106. https://doi.org/10.1007/s10646-011-0671-8

[28] Tanouayi, G., Gnandi, K., Ahoudi, H. and Ouro-Sama, K (2015) Contamination metallique des eaux de surface et des eaux souterraines de la zone miniere d'exploitation des phosphates de hahotoe-kpogame (sud-togo): Cas du cadmium, plomb, cuivre et nickel. Larhyss Journal, 2, 25-40.

[29] Singh, L., Choudhary, S.K. and Singh, P.K. (2011) Organochlorine and Organophosphorus Pesticide Residues in Water of River Ganga at Bhagalpur, Bihar, India. International Journal of Research in Chemistry and Environment, 1, 77-84.

[30] Gnonsoro, U.P., Yao, K.M., Yao, B.L., Kouassi, N.L.B., Dembele, A., Metongo, S.B., Kouassi, A.M. and Trokourey, A. (2016) Aldicarbe et crimidine dans les eaux et les sédiments aux alentours de la décharge municipale d'Akouédo (Abidjan, Côte d'Ivoire): Niveaux et fréquences de contamination. The International Journal of Biological and Chemical Sciences, 10, 400-411.

https://doi.org/10.4314/ijbcs.v10i1.30

[31] Palma, P., Kuster, M., Alvarenga, P., Palma, V.L., Fernandes, R.M., Soares, A.M.V.M., López, M.J., de Alda Barceló, D. and Barbosa I.R. (2009) Risk Assessment of Representative and Priority Pesticides, in Surface Water of the Alqueva Reservoir (South of Portugal) Using on-Line Solid Phase Extraction-Liquid Chromatography-Tandem Mass Spectrometry. Environment International, 35, 545-551. https://doi.org/10.1016/j.envint.2008.09.015

[32] Weber, J.B., Wilkerson, G.G. and Reinhardt, C.F. (2004) Calculating Pesticide Sorption Coefficients (Kd) Using Selected Soil Properties. Chemosphere, 55, 157-166. https://doi.org/10.1016/j.chemosphere.2003.10.049

[33] Amadou, D. (2013) Diagnostic des pratiques d'utilisation et quantification des pesticides dans la zone des Niayes de Dakar. Thèse de doctorat de l'Université du Littoral Côte d'Opale, Sénegal, 241 p. 
[34] Cruzeiro, C., Rocha, E., Pardal, M.A. and Rocha, M.J. (2016) Seasonal-Spatial Survey of Pesticides in the Most Significant Estuary of the Iberian Peninsula-The Tagus River Estuary. Journal of Cleaner Production, 1-27. https://doi.org/10.1016/j.jclepro.2016.03.005

[35] Volodymyr, I.L., Tetiana, M.M., Viktor, H. and Janet, M.S. (2018) Pesticide Toxicity: A Mechanistic Approach. EXCLI Journal, 17, 1101-1136.

[36] Ghasemidehkordi, B., Malekirad, A.A., Nazem, H., Fazilati, M., Salavati, H., Shariatifar, N. and Khaneghah, A.M. (2018) Concentration of Lead and Mercury in Collected Vegetables and Herbs from Markazi Province, Iran: Non-Carcinogenic Risk Assessment. Food and Chemical Toxicology, 113, 204-210. https://doi.org/10.1016/j.fct.2018.01.048

[37] Heshmati, A., Ghadimi, S., Mousavi Khaneghah, A.J., Barba, F.M., Lorenzo, J., Nazemi, F. and Fakhri, Y. (2018) Risk Assessment of Benzene in Food Samples of Iran's Market. Food and Chemical Toxicology, 114, 1-12.

https://doi.org/10.1016/j.fct.2018.02.043

[38] Lekkas, T., Kolokythas, G., Nikolaou, A., Kostopoulou, M., Kotrikla, A., Gatidou, G., Nikolaos, S., Thomaidis, Golfinopoulos, S., Makri, C., Babos, B., Vagi, M., Stasinakis, A., Petsas, A. and Demetris, F. (2004) Evaluation of the Pollution of the Surface Waters of Greece from the Priority Compounds of List II, 76/464/EEC Directive, and Other Toxic Compounds. Environment International, 30, 995-1007. https://doi.org/10.1016/j.envint.2004.04.001

[39] Friedl, G., Teodoru, C. and Wehrli, B. (2004) Is the Iron Gating I Reservoir on the Danube River a Sink for Dissolved Silica? Biogeochemistry, 68, 21-32. https://doi.org/10.1023/B:BIOG.0000025738.67183.c0

[40] Gala-Gorchev, H. (1996) Chlorine in Water Disinfection. Pure and Applied Chemistry, 68, 1731-1735. https://doi.org/10.1351/pac199668091731

[41] Brunet, F., Dubois, K., Veizer, J., Nkoue Ndondo, G.R., Ndam Ngoupayou, J.R., Boeglin, J.L. and Probst, J.L. (2009) Terrestrial and Fluvial Carbon in Tropical Watershed: Nyong Basin, Cameroon. Chemical Geology, 265, 563-572. https://doi.org/10.1016/j.chemgeo.2009.05.020

[42] Olasoji, S.O., Oyewole, N.O., Bayode. A. and Joshua, N.E. (2019) Water Quality Assessment of Surface and Groundwater Sources Using a Water Quality Index Method: A Case Study of a Peri-Urban Town in Southwest, Nigeria. Environments, 6, 23. https://doi.org/10.3390/environments6020023

[43] Amaal, M.A.-S., Mohamed, H.A. and Mohamed, E.G. (2017) Indices of Water Quality and Metal Pollution of Nile River, Egypt. Egyptian Journal of Aquatic Research, 43, 21-29. https://doi.org/10.1016/j.ejar.2016.12.006

[44] Vuori, K. (1995) Direct and Indirect Effects of Iron on River Ecosystems. Annales Zoologici Fennici, 32, 317-329. 